JELENA M. JAKŠIĆ *

Institute of Chemical Engineering Sciences, FORTH, Stadiou Str., Platani, Patras, Greece

Scientific paper

ISSN 0351-9465, E-ISSN 2466-2585

UDC:620.19:621.791.037

doi:10.5937/ZasMat1601013J

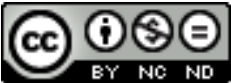

Zastita Materijala 57 (1)

$13-25(2016)$

\title{
Primary oxide (Pt-OH) latent storage induced spillover and reversible electrocatalysts for oxygen electrode reactions
}

\begin{abstract}
Primary oxide (Pt-OH) latent storage and electrocatalytic spillover properties for the reversible oxygen electrode (ROE) behavior have been identified and substantiated, back and forth, all along the potential axis between hydrogen and oxygen evolving limits. Such advanced electrocatalytic properties imply interactive (SMSI - Strong Metal-Support Interaction) nanostructured Pt (Au, RuPt) clusters grafting upon composite mixed valence hypo-d-(f)-oxide supports, the latter featuring extra high stability and pronounced electronic conductivity, along with spontaneous dissociative water molecules adsorption, and resulting renewable primary oxide latent storage by continuous vapor supply and membrane type hydroxide ions surface migration. The latter as individual species, under imposed polarization transfer their prevailing part of electrons to the metallic electrocatalyst, thence resulting as $\mathrm{Pt}-\mathrm{OH}(\mathrm{Au}-\mathrm{OH})$ dipoles, and by their surface repulsion obey reversible spillover distribution and impose the electrocatalytic ROE properties all over the catalyst surface and DL pseudo-capacitance charging and discharging.

Keywords: Primary oxide (Pt-OH, Au-OH, M-OH); surface oxide (Pt=O,Au=O); spillover (effusion); SMSI (Strong Metal-Support Interaction); d-(f)-metallic properties, UPD (OPD) double layer $(D L)$ charging/discharging pseudo-capacitance; nanostructured bronze type electrocatalyst; alterpolar revertible cell.
\end{abstract}

\section{INTRODUCTION}

Ever since Sir William Grove [1] invented fuel cells (FCs), reversible oxygen electrocatalysis has been the main imperative target, challenge and dream of the entire electrochemical science, primarily focused on noble ( $\mathrm{Pt}, \mathrm{Au}$ ) metals, while the reversible primary $(\mathrm{Pt}-\mathrm{OH}, \mathrm{Au}-\mathrm{OH})$ and polarizable surface $(\mathrm{Pt}=\mathrm{O}, \mathrm{Au}=\mathrm{O})$ oxides, along with $\mathrm{H}$ adatoms $(\mathrm{Pt}-\mathrm{H}, \mathrm{Au}-\mathrm{H})$ represent interactive species defining the overall electrode behavior and properties. In such a respect potentiodynamic spectra usually reveal within a narrow potential range the highly reversible peaks of primary oxide adsorptive growth and desorptive removal [2,3],

$$
\mathrm{Pt}+2 \mathrm{H}_{2} \mathrm{O} \leftrightarrow \mathrm{Pt}-\mathrm{OH}+\mathrm{H}_{3} \mathrm{O}^{+}+e^{-}
$$

${ }^{*}$ Corresponding author: Jelena Jakšić

Email: jelena@iceht.forthe.gr

Paper received: 14. 08. 2015.

Paper accepted: 25. 09. 2015.

Paper is available on the website: www.idk.org.rs/journal as a typical double layer (DL) charging and discharging pseudo-capacitance [4-7], which soon later disproportionates into the strongly polarizable, more adsorptive and more stable surface oxide $(\mathrm{Pt}=\mathrm{O})$ monolayer $[2,3]$,

$$
\mathrm{Pt}-\mathrm{OH}+\mathrm{H}_{2} \mathrm{O} \rightarrow \mathrm{Pt}=\mathrm{O}+\mathrm{H}_{3} \mathrm{O}^{+}+e^{-}
$$

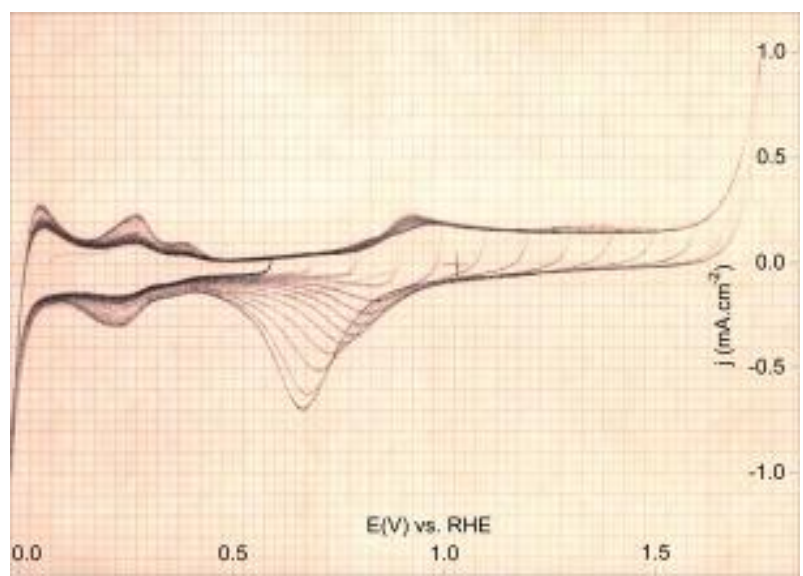

Figure 1 - Cyclic voltammograms of polycrystalline Pt scanned in $0.1 \mathrm{M} \mathrm{NaOH}$ at sweep rate $100 \mathrm{mV} . \mathrm{s}^{-1}$ 
The latter imposes such a critical and typical, very pronounced reaction polarization range (Fig. 1) all along until oxygen evolving potential limits, and in both scan directions [4-7].

Such highly reversible (Eq. 1), relative to the subsequent strongly irreversible and substantially polarizable (Eq. 2) transient, has been decisive as concerns the overall electrocatalytic oxygen (ORR and OER) properties of both $\mathrm{Pt}$ and $\mathrm{Au}$ electrode. Since the equimolar ratio of the primary and surface oxide concentration defines the optimal interfering self-catalytic spillover reaction step in cathodic oxygen reduction reaction (ORR) [8],

$\mathrm{Pt}-\mathrm{OH}+\mathrm{Pt}=\mathrm{O}+3 \mathrm{H}_{3} \mathrm{O}^{+}+3 e^{-} \rightarrow 5 \mathrm{H}_{2} \mathrm{O}+2 \mathrm{Pt}$

the irreversible disproportionation (Eq. 2) imposes an extremely high reaction polarization barrier (see later downwards) that amounts for even more than $600 \mathrm{mVs}$ and then, in absence of the $\mathrm{Pt}-\mathrm{OH}$, makes plain $\mathrm{Pt}$ (and $\mathrm{Au}$ ) and non-interactive supported both $(\mathrm{Pt} / \mathrm{C}$ or $\mathrm{Au} / \mathrm{C})$ platinum and gold irreversible for the oxygen electrode reactions. In other words, plain and non-interactive $(\mathrm{Pt} / \mathrm{C}$ and/or $\mathrm{Au} / \mathrm{C})$ supported $\mathrm{Pt}(\mathrm{Au})$ electrodes themselves by no means can behave electrocatalytic features of the reversible oxygen electrode (ROE) all along the potential axis between hydrogen and oxygen evolving limits. The strongly adsorptive and thence highly polarizable $\mathrm{Pt}=\mathrm{O}(\mathrm{Au}=\mathrm{O})$, deprived from any local and/or the external Pt-OH (Au-OH) supply, defines one of the most pronounced issues of the reaction polarization in the entire electrochemical science: No Pt-OH, means that there is no reversible reaction (Eq. 3).

\section{ELECTROCATALYSIS AND SPILLOVER ELECTROCATALYSTS FOR THE ROE}

Whereas hydrogen molecules undergo spontaneous adsorptive dissociation on plain $\mathrm{Pt}$ $(\mathrm{Pt} / \mathrm{C})$ yielding $\mathrm{H}$-adatoms $(\mathrm{Pt}-\mathrm{H})$ to establish thermodynamic equilibrium of the RHE (Reversible Hydrogen Electrode, $\left.\left(\mathrm{Pt}\left(\mathrm{H}_{2}\right) / \mathrm{Pt}-\mathrm{H} / \mathrm{H}_{3} \mathrm{O}^{+}\right)\right)$, within the above identified critical potential range $\mathrm{Pt}(\mathrm{Au})$ is deprived (Eq. 2), from the Pt-OH $(\mathrm{Au}-\mathrm{OH})$ to provide reversible properties for the $\mathrm{ROE}$ $\left(\left(\mathrm{Pt}\left(\mathrm{O}_{2}\right) / \mathrm{Pt}-\mathrm{OH}, \mathrm{Pt}=\mathrm{O}\right) / \mathrm{OH}^{-}\right)$, and both together from the reversible hydrogen fueled L\&MT PEMFCs. In other words, the $\mathrm{Pt}-\mathrm{OH}(\mathrm{Au}-\mathrm{OH})$ plays the same thermodynamic constitutional role for establishing the equilibrium ROE, as $\mathrm{Pt}-\mathrm{H}$ does for the RHE, and thence, unavoidably imposes continuous need and requires a permanent source of the former to overcome the reaction polarization and enables the reversible electrocatalytic properties of the ROE [47]. In such a respect, the first main step in the present concept towards the ROE implies that catalytic hyper-d-metals (Pt,Au,Ru) establish with hypo-d-(f)-oxides (or their mixed valence compo- unds, like $\mathrm{Nb}_{2} \mathrm{O}_{5}, \mathrm{TiO}_{2}, \mathrm{CeO}_{2}$ or $\mathrm{Ta}_{2} \mathrm{O}_{5}, \mathrm{TiO}_{2}, \mathrm{CeO}_{2}$ ) the interactive Brewer type (d-d or $d-f$ ) bonding effect $[9,10]$, otherwise well known in heterogeneous catalysis as Tauster [11] SMSI (Strong Metal-Support Interaction), one of the strongest in the entire chemistry (Scheme 1,[4]). Consequently, this way interactive inter-bonded composite electrocatalysts (example, $\mathrm{Pt} / \mathrm{Nb}_{2} \mathrm{O}_{5}, \mathrm{TiO}_{2}$ ) impose remarkably stretched d-orbitals, and thereby exhibit much weaker adsorptive interbonding strengths of intermediates ( $\mathrm{Pt}-\mathrm{H}, \mathrm{Pt}-\mathrm{OH}$ ) in the RDSs (Rate Determining Steps), thence correspondingly facilitated cleavage of the latter, and thereby, increased the catalytic activity both for hydrogen and oxygen electrode reactions. Meanwhile, some other accompanying effects, in particular the ones associated with the $\mathrm{Pt}-\mathrm{OH}$ spillover, play more significant role for the latter. First, hypo-d-oxides and their mixed valence compounds exhibit extra high stability in both acidic and alkaline media, and many of them pronounced (above $300 \mathrm{~S} / \mathrm{cm}$ ) electron conductivity (ending with $1,000 \mathrm{~S} / \mathrm{cm}$ for Magneli phases).

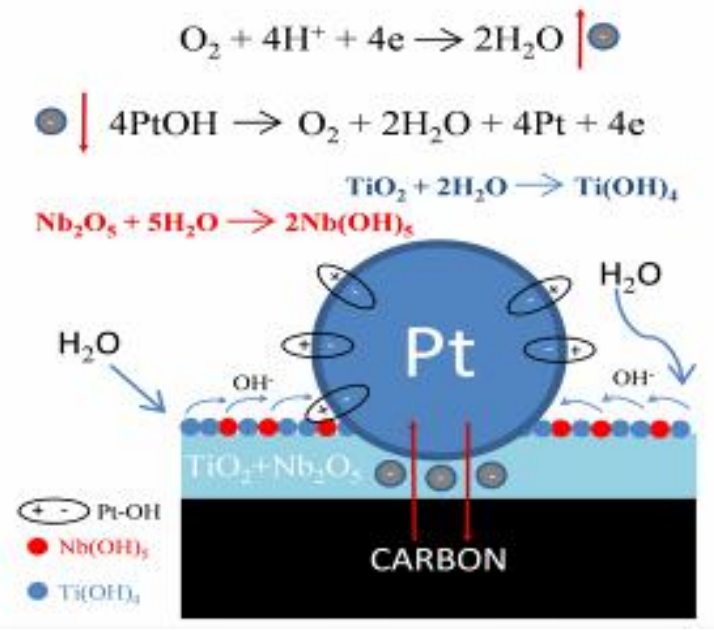

Scheme 1 - Visual presentation of novel spillover latent storage Pt-OH type interactive supported electrocatalyst for oxygen electrode reactions, exampled for $\mathrm{Pt} / \mathrm{Nb}_{2} \mathrm{O}_{5}, \mathrm{TiO}_{2} / \mathrm{Nb}(\mathrm{OH})_{5}, \mathrm{Ti}(\mathrm{OH})_{4}$ issue

Furthermore, majority of hypo-d-(f)-oxides and in particular of higher altervalent numbers, feature prevailingly high percentage of dissociative water molecules adsorption [12,13], (Eq. (1-a)), and thence, the mostly enhanced surface membrane type of hydroxyl ions migration mass transfer [14], (Eq. (1-b) and (1-c)),

$$
\begin{aligned}
& \mathrm{Nb}_{2} \mathrm{O}_{5}+5 \mathrm{H}_{2} \mathrm{O} \leftrightarrow 2 \mathrm{Nb}(\mathrm{OH})_{5} \\
& \mathrm{Nb}(\mathrm{OH})_{5}+\mathrm{Pt} \rightarrow \mathrm{Nb}(\mathrm{OH})_{4}^{+}+\mathrm{M}-\mathrm{OH}+e^{-} \\
& \mathrm{Nb}(\mathrm{OH})_{4}^{+}+2 \mathrm{H}_{2} \mathrm{O} \rightarrow \mathrm{Nb}(\mathrm{OH})_{5}+\mathrm{H}_{3} \mathrm{O}^{+}
\end{aligned}
$$


ending up with the prevailing electron transfer to the interactive supported metallic catalyst, so that the $\mathrm{Pt}-\mathrm{OH}$ behaves as a pronounced dipole species [15], and thus, exhibits the strong spillover surface transfer and distribution. At the same time, the highly pronounced reversible potentiodynamic peaks testify for the extremely fast overall spillover reaction (Eq. 1), in both directions [2,3], primarily used for DL charging and discharging, and being ready and available for fast heterogeneous electrocatalytic reactions. In the same context, it would be significant inferring that whenever anodic oxidation reactions of the $\mathrm{Pt}-\mathrm{OH}(\mathrm{Au}-\mathrm{OH})$, exceed at least for an order of magnitude the disproportionation rate (Eq. 2), such as the ones with $\mathrm{HCHO}$ [4-7], and other aldehydes, simple alcohols and their acids, then this way these succeed highly to suppress and remarkably postpone the $\mathrm{Pt}=\mathrm{O}$ growth all along the potential axis till the close proximity of oxygen evolving limits, and consequently show enormous broad extension growth of the Pt-OH (Au-OH) adsorption peak (Fig. 2, [4]).

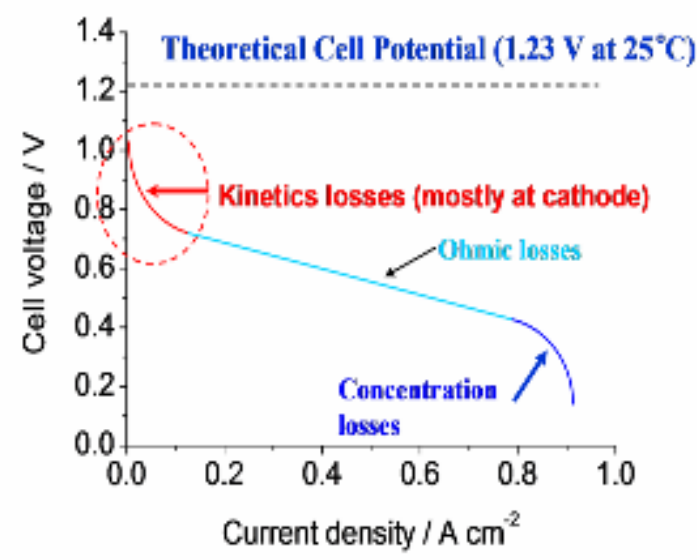

Figure 2 - Classical and characteristic energy chart diagram for nanostructured Pt/C electrocatalyst in $L T$ PEMFCs (constructed and courtesy by R. Adzic).

In such an overall constellation, individual hypo-d-(f)-oxides, and even more so their mixed valence composite compounds, when in expanded (sol-gel synthesis with thorough liquid $\mathrm{CO}_{2}$ supercritical drying) hydrated surface state, behave as unlimited latent storage and spillover sources of the primary oxide $[4,6,16,17]$, continuously being renewed and recovered simply by water vapor supply and instantaneously proceeding spontaneous dissociative adsorption of water molecules. In such a respect, it is certainly worth mentioning the auto-catalytic Ertel [18] effect of water molecules for the Pt-OH growth that mostly occurs in all heterogeneous oxidation processes, particularly when these appear as dipoles polarized within double layers (Eq. 1). Haruta [19] in the same sense has pointed out the lowest threshold moisture content below which there is no $\mathrm{CO}$ oxidation upon interactive supported catalysts (nanostructured $\mathrm{Au} / \mathrm{TiO}_{2}$ ). Meanwhile, Boudart $[20,21]$ inferred on the continuous minimal monolayered vapor condensation as precondition for fast spillover of $\mathrm{H}$ adatoms upon hydrated $\left(\mathrm{Pt} / \mathrm{Nb}(\mathrm{OH})_{5}\right)$ state, and vice versa, the same for the Pt-OH [2,3], even at ambient temperature, while in dried oxide state, it needs $400{ }^{\circ} \mathrm{C}$. In fact, there establishes an entirely thermodynamic equilibrium $\left(\mathrm{Pt} / \mathrm{H}_{\mathrm{x}} \mathrm{Nb}_{2} \mathrm{O}_{5} \leftrightarrow\right.$ $\left.\mathrm{Pt} / \mathrm{Nb}(\mathrm{OH})_{5}\right)$, which enables the reversible alterpolar interchanges and therefrom the substantiation of superior revertible cells altering between PEMFCs and WE (Water Electrolysis), otherwise of substantial significance for the hydrogen energy balance and performances (overnight energy sufficiencies, and daily deficiencies). In other words, no spillover of primary oxides $(\mathrm{Pt}-\mathrm{OH}, \mathrm{Au}-$ $\mathrm{OH})$, means that there are no reversible alterpolar changes and no advanced revertible cells!

In general, nanostructured $\mathrm{Pt}(\mathrm{Au})$ electrocatalysts selectively interactive grafted upon hypo-d-(f)oxide supports, when the latter exists in the hydrated external surface state (Scheme), and thence consequently exhibits enriched $\mathrm{Pt}-\mathrm{OH}(\mathrm{Au}-\mathrm{OH})$ latent storage, as the feedback oxophilicity effect and property, so that the corresponding primary oxide continuously features renewable spillover, simply by water vapor supply (surface phenomena, no concentration polarization), and further continuously resulting spontaneous dissociative adsorption of aqueous species, then the reversible anodic oxygen evolution (Eq. 4) takes place straight from pronouncedly exaggerated and also the highly reversible $\mathrm{Pt}-\mathrm{OH}(\mathrm{Au}-\mathrm{OH})$ adsorptive peak capacities (Fig. 3 and 4) $[5,16]$

$$
4 \mathrm{Pt}-\mathrm{OH} \leftrightarrow \mathrm{O}_{2}+2 \mathrm{H}_{2} \mathrm{O}+4 \mathrm{Pt}+4 \mathrm{e}^{-}
$$

and, thence, at the thermodynamic equilibrium (ROE) potential value.

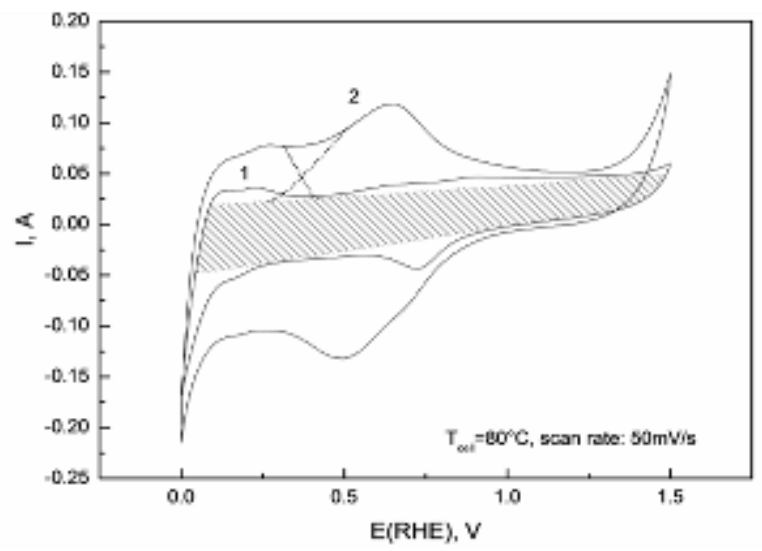

Figure 3 - Cyclic voltammograms of interactive (SMSI) supported nanostructured Pt electrode $\left(\mathrm{Pt} / \mathrm{TiO}_{2}, \mathrm{WO}_{3} / \mathrm{C}\right)$, on mixed valence hypo-d-oxides, scanned in He stream, ones at negligible moisture content (curve 1) and at $80^{\circ} \mathrm{C}$ water vapor saturation (curve 2) (scanned by D. Labou). 
Quite on the contrary, in classical issues (Fig. 1), the latter occurs from the strong irreversibly deposited and highly polarizable monolayer of the $\mathrm{Pt}=\mathrm{O}$, (Eq. 2), and thereby, while being deprived from primary oxides, at rather high anodic overpotentials,

$$
2 \mathrm{Pt}=\mathrm{O} \rightarrow \mathrm{O}_{2}+2 \mathrm{Pt}+4 \mathrm{e}
$$

and vice versa, the same occurs both in these reversible and/or irreversible states, as concerns the ORR, all along the reverse cathodic scan and polarization (Figs. 1, 3 and 4) [4].

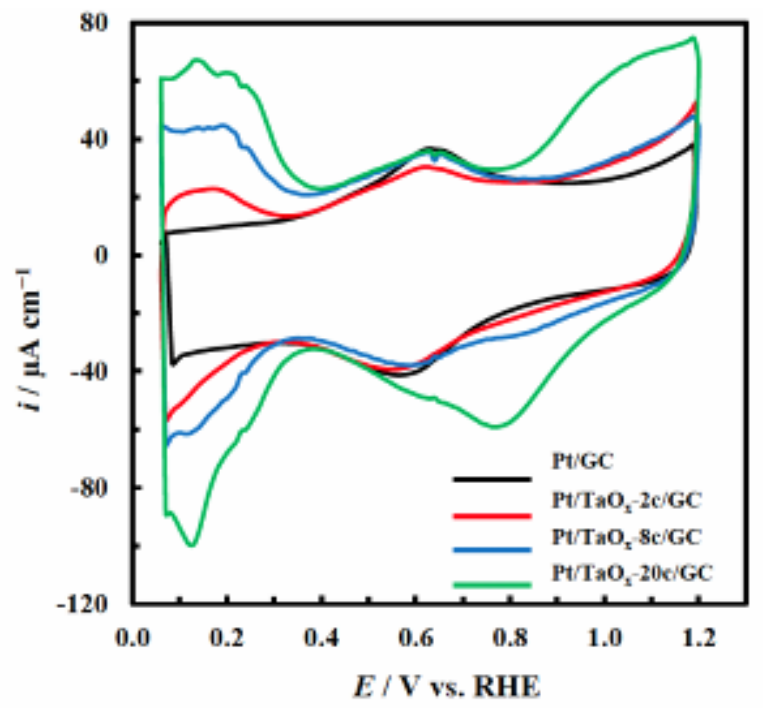

Figure 4 - Cyclic voltammograms scanned at the $\mathrm{Pt} / \mathrm{GC}$ an $\mathrm{Pt} / \mathrm{TaO}$ / $/ \mathrm{GC}$ catalytic electrodes with $2 \mathrm{c}$, $8 \mathrm{c}$, and 20c (cycles) in Ar-saturated $0.5 \mathrm{M} \mathrm{H}_{2} \mathrm{SO}_{4}$ solution at scan rate of $50 \mathrm{mV} . \mathrm{s}^{-1}$, revealing the effect of proportional increasing of interactive $\mathrm{Pt}$ supporting $\mathrm{Ta}_{2} \mathrm{O}_{5}$ deposit on the Pt-OH spillover effect and growth for the ORR (courtesy by $T$. Ohsaka [16])

The transient between the reversible and irreversible status features some sharp thresholds both as a function of hypo-d-(f)-oxide unit content and/or wetness percentage (Figs. 3 and 4, [4]), and substantially reflects the $\mathrm{Pt}-\mathrm{OH}(\mathrm{Au}-\mathrm{OH})$ properties (present or absent) for the oxygen electrode reactions [4-6]. In such a context, plain and noninteractive supported $\mathrm{Pt}(\mathrm{Pt} / \mathrm{C})$, in the absence of primary oxides, and thereby established or a priori existing the broad reaction polarization range, by no means can feature the overall reversible oxygen electrode properties within the whole potential axis, in between of the hydrogen and oxygen evolving limits. Thus, there exists either the reversible behavior in the presence or continuous external supply of primary oxides, or highly irreversible properties in the absence of the Pt-OH $(\mathrm{Au}-\mathrm{OH})$, and this is the substance for $\mathrm{Pt}$ and $\mathrm{Au}$ electrocatalytic properties! In such a context, the simple stoichiometric combination of Eq.1 and Eq. 4 , reveals that the overall reversible anodic oxygen evolution initiates from water molecules and obeys the auto- or self-catalytic Ertel framework [18], with the general oxidation mechanism based on and catalyzed by $\mathrm{M}-\mathrm{OH}$ species, or the primary oxides as the main interfering electrocatalytic species, and substantially takes place at the reversible oxygen potential value; the same in the reverse cathodic ORR scans. However, when oxygen evolving initiates from $\mathrm{Pt}(\mathrm{Au})$ monolayer covered by the strongly adsorptive and polarizable surface oxide $(\mathrm{Pt}=\mathrm{O} . \mathrm{Au}=\mathrm{O})$, the anodic, and reverse cathodic reaction have both to overcome remarkable overpotentials (Eq. 5, adjoined with Eq. 2). This is the substance and difference as concerns the irreversible plain $(\mathrm{Pt}, \mathrm{Au})$ and non-interactive supported $(\mathrm{Pt} / \mathrm{C}, \mathrm{Au} / \mathrm{C})$, and/or the enriched latent storage and continuous external spillover feeding of the primary oxide for interactive hypo-d-(f)-oxides supported $\mathrm{Pt}$ ) electrode.

\section{ELECTROCATALYTIC CONSEQUENCES}

Since $\mathrm{Pt}(\mathrm{Au})$ electrocatalyst becomes interactive $d-d-(f)$-bonded with and grafting fixed upon hypo-d-(f)-oxide type catalytic supports in new composite nano-structure, there is no more its metallic surface diffusion and agglomeration, nor any Nafion membrane cross-over of hydrogen. Even more so, from the same reasons, the life-time of $\mathrm{Pt}(\mathrm{Au})$ is at least twice longer and can be guaranteed. Alterpolar changes in the revertible PEMFC versus WE proceed reversibly and instantaneous smoothly and enable their superior unique operation and interchanges. There is a great number of parametric and structural variability for the voltage/ current optimization and stability, such as hypo-doxide radius of small, medium and large $d-(f)$ metals (Y,Ti,Nb,Ta,W,Ce,Ho,La, etc.), to keep low Tafel slope within $0-1.0 \mathrm{~A} \mathrm{~cm}^{-2}$. Since some of hypo-d-(f)-oxide supports of composite electrocatalysts (NbO, $\mathrm{TaO}, \mathrm{TiO})$ feature advanced electron conductivity, nano-particulate carbon carriers and current collectors can be completely avoided that is substantially significant for WE and mostly for anodic oxygen evolution. In such a respect, the present paper defines the main substantial and advantageous frameworks in electrocatalysis of reversible electrocatalysts for oxygen electrode reactions (mostly ORR and OER), primarily for L\&MT PEMFCs, WE, and revertible combinations, and as the overall main conclusion, hopefully means the most important contribution all after Sir William Grove. All stated herein for $\mathrm{Pt}$, means even more for $\mathrm{Au}$ when oxygen electrode reactions are in consideration (ORR, OER) [22-27]. The actual target: Tafel 
slopes $60 \mathrm{mV} / \mathrm{dec}$, or $\eta=180 \mathrm{mV}$ at $1,000 \mathrm{~mA} / \mathrm{cm}^{2}$, or ideal $30 \mathrm{mV} / \mathrm{dec}$, or $90 \mathrm{mV}$ at $1.0 \mathrm{~A} / \mathrm{cm}^{2}$.

\section{STEP BY STEP THEORY DEVELOPMENT AND CONFIRMATION}

Although $\mathrm{Pt}$ best satisfies electrocatalytic requirements of PEMFCs for hydrogen electrode reactions (HER), both common energy chart diagrams (Fig. 2), and interconnected cyclic voltammograms (Fig. 1) heuristically show that the reversible behavior for cathodic oxygen reduction (ORR), like a broad plateau in the energy conversion, starts within the potential range of reversible peak of the $\mathrm{Pt}-\mathrm{OH}$ desorption and consequently, overall loses within the preceding critical potential range amount for more than half of thermodynamic available value; or about $600 \mathrm{mVs}$. The main obstacle arises as the reaction polarization between the reversible adsorption/desorption peaks of the primary oxide growth and removal (Eq. 1), and anodic oxygen evolution, in both potential scan directions, as the result of irreversible disproportionation (Eq. 2) of Pt-OH (Au-OH) into highly polarizable and strongly adsorbing surface oxide $(\mathrm{Pt}=\mathrm{O}, \mathrm{Au}=\mathrm{O})$. Thus, ever since Sir William Grove [1] invented fuel cells (FCs), the electrocatalytic search for the reversible oxygen electrode (ROE), and most particularly the ORR, became the main challenge and imperative target in electrochemistry of aqueous and PEM media, while its substantiation is the subject matter of the present paper. The substance is to replace the potential range of the reaction polarization of the monolayered surface oxide by the reversible electrocatalysis and make $\mathrm{Pt}(\mathrm{Au})$ catalytically active all over the potential axis between hydrogen and oxygen evolving limits, back and forth.

\section{GENERAL THEORY AND ITS SUBSTANTIATION}

Whereas hydrogen molecules undergo spontaneous adsorptive dissociation on plain $\mathrm{Pt}$ and noninteractive supported $(\mathrm{Pt} / \mathrm{C})$ and $\mathrm{H}$-adatoms $(\mathrm{Pt}-\mathrm{H})$ establish thermodynamic equilibrium of the RHE (Reversible Hydrogen Electrode, $\left(\mathrm{Pt}\left(\mathrm{H}_{2}\right) / \mathrm{Pt}-\right.$ $\left.\mathrm{H} / \mathrm{H}_{3} \mathrm{O}^{+}\right)$), within the above identified critical reaction polarization range $\mathrm{Pt}(\mathrm{Au})$ is deprived from the $\mathrm{Pt}-\mathrm{OH}$ to provide reversible properties for the ROE $\left(\left(\mathrm{Pt}\left(\mathrm{O}_{2}\right) / \mathrm{Pt}-\mathrm{OH}, \mathrm{Pt}=\mathrm{O}\right) / \mathrm{OH}^{-}\right)$, and both together the reversible hydrogen fueled L\&MT PEMFCs. In other words, the substantial and decisive point is that even within the highly reversible peak of the anodic Pt-OH growth, (Eq. 1), there immediately proceeds the strongly adsorptive and highly polarizable electrode process of its irreversible $\mathrm{Pt}-\mathrm{OH}$ $(\mathrm{Au}-\mathrm{OH})$ disproportionation into the stable surface oxide $(\mathrm{Pt}=\mathrm{O})$, (Eq. 2), and imposes such a critical polarization range (Fig. 1 and 2) all along until anodic oxygen evolution, and equally so in the reverse scan direction.

In such a respect, polarization properties of some typical and characteristic novel interactive hypo-d-oxides supported nanostructured $\mathrm{Pt}$ electrocatalysts for both the ORR and OER $[4,22]$, enable to select some diagnostic kinetic criterions on the way towards the ROE, revealing from their Tafel plots: (i) Nano-dispersed Pt/C clusters (10 wt.\% Pt) adhering upon sol-gel developed indifferent nano-particulate E-tek, Inc., Vulcan-XC-72 carbon (240 sq.m/g) carrier and current collecting species, considered for the classical issue of such an electrocatalytic activity comparison; (ii) The interactive supported nanostructured $\mathrm{Pt}$ particles upon both the extra stable and electron conductive (300 - 1,000 S/cm), ceramic Magneli phases (Ebonex $\left.{ }^{\circledR}\right), \mathrm{Ti}_{n} \mathrm{O}_{(2 \mathrm{n}-1)}$, in average $\mathrm{Ti}_{4} \mathrm{O}_{7}$, usually defined as a shared rutile structure, accommodating the oxygen suboxide deficiency in the structure by the formation of crystal shared planes along the nth layerlike plane of octahedron, so that $\mathrm{Ti}_{4} \mathrm{O}_{7}$, has one $\mathrm{TiO}$ for every three $\mathrm{TiO}_{2}$ layers; (iii) Advanced interactive selective grafted and homogeneously distributed nanostructured $\mathrm{Pt}$ clusters down to the prevailing $(2.2 \pm 0.2 \mathrm{~nm})$ nano-size, upon the optimized structure of mixed valence hypo-d-oxide compounds $\left(\mathrm{Pt} / \mathrm{Nb}_{2} \mathrm{O}_{5}, \mathrm{TiO}_{2} / \mathrm{C}\right)$, and even further extended (iv) composites with hypo-f-oxides $\left(\mathrm{Pt} / \mathrm{Nb}_{2} \mathrm{O}_{5}, \mathrm{CeO}_{2}, \mathrm{TiO}_{2} / \mathrm{C}\right.$, including doped $\mathrm{GdO}_{2}$, $\mathrm{HoO}_{2}$, and $\mathrm{LaO}_{2}$ itself), and their relative combinations of extra high stability and remarkable electron conductivity, too.

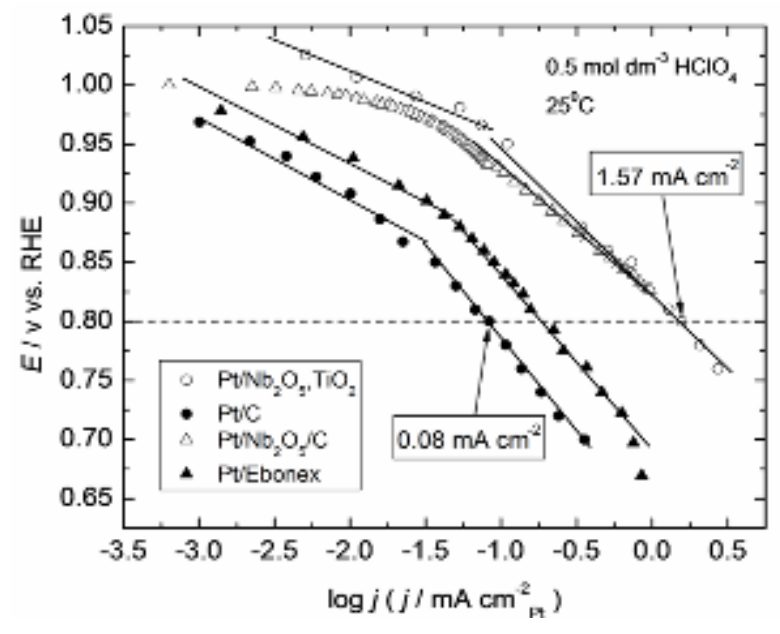

Figure 5 - Tafel plots for the cathodic ORR scanned on RDE in $0.5 \mathrm{M} \mathrm{HClO}_{4}$ solution at $25^{\circ} \mathrm{C}$ for E-tek, Inc., Pt/C (Vulcan XP-72, closed circles); Pt/Ebonex (Magneli phases, closed triangles); $\mathrm{Pt} / \mathrm{Nb}_{2} \mathrm{O}_{5}$ (20 wt.\%)/C (70 wt.\%) (open triangles); and $\mathrm{Pt} / \mathrm{Nb}_{2} \mathrm{O}_{5}$ (5 mol.\%), $\mathrm{TiO}_{2}$ (95 mol.\%) (open circles) (Pt 10 wt.\% in all issues), (scans and search N.V.Krstajic) 
Such comparable diagnostic Tafel polarization interdependences distinctly display Fig.5, with differences of more than an order of magnitude in the electrocatalytic activity for the ORR that arise only as the result of different hypo-d-f-oxide type of interactive catalyst supports, relative ratios of their amounts versus metallic part of the catalyst $(\mathrm{Pt})$, and their corresponding SMSI [11].

\section{LEADING IDEA FOR THE ROE ELECTROCATALYSTS}

Some subtle potentiodynamic survey of fundamental significance has then been focused on the actual mixed interfering $\mathrm{Pt}-\mathrm{OH} / \mathrm{Pt}=\mathrm{O}$ coverages at selected points (Fig. 6, a\&b) within the characteristic potentials close to the open circuit value and all along the reversible potential range of low Tafel line slopes (mostly $30 \mathrm{mV} / \mathrm{dec}$ ).

The main conclusions then have been that $\mathrm{Pt}$ electrodes, both plain and interactive supported upon hypo-d-oxides, have been covered by mixed Pt oxides, while at higher irreversible polarization $(120 \mathrm{mV} / \mathrm{dec})$, they were completely deprived from such adsorptive layers. In other words, while within the reversible range, the ORR is associated with and proceeds upon mixed oxide covered Pt surface, as the interfering self-catalytic spillover electrode process, (Eq. 3), otherwise known as the fastest reaction step [8], the oxide-free Pt surface imposes much higher polarization for the direct electron transfer reaction to occur. Thus, the conclusive observation has now been that $\boldsymbol{P t}$ oxides (in particular the Pt-OH), play the same self-catalytic role to establish the ROE properties, as the spontaneous hydrogen $(\mathrm{Pt}-\mathrm{H})$ adsorption does and means for the RHE. In fact, the leading idea consists now from the extension of the reversible Tafel plot for the ORR all along the potential axis down from or up to the thermodynamic value (1.29 V vs. RHE) that implies enriched external latent $\mathrm{Pt}-\mathrm{OH}$ storage and continuous spillover supply all along in both scan directions, and particularly within the critical potential range (Fig. 1 and 2). Namely, so far the problem and obstacle were the initial highly reaction polarizable potential range of strongly adsorbed monolayered $\mathrm{Pt}=\mathrm{O}$ and missing the $\mathrm{Pt}$ $\mathrm{OH}$, which cannot be supplied from aqueous solution, but only as the adsorptive species. These rather specific potentiodynamic measurements even more clearly show that the ORR upon $\mathrm{Pt} /$ Ebonex starts and finishes at remarkably more positive potential values (1.05 down to $0.86 \mathrm{~V}$, versus 0.95 down to $0.8 \mathrm{~V}$, all versus the $\mathrm{RHE}$ ), relative to polycrystalline $\mathrm{Pt}$ metal and/or nanostructured $\mathrm{Pt} / \mathrm{C}[4,22]$; whereas the other two congenial issues (iii \& iv) initiate with $1.29 \mathrm{~V}$ as the completed reversible property of the ROE (Fig. 3 and 4). These have been decisive observations of substantial significance for reversible electrocatalysis in oxygen electrode reactions.

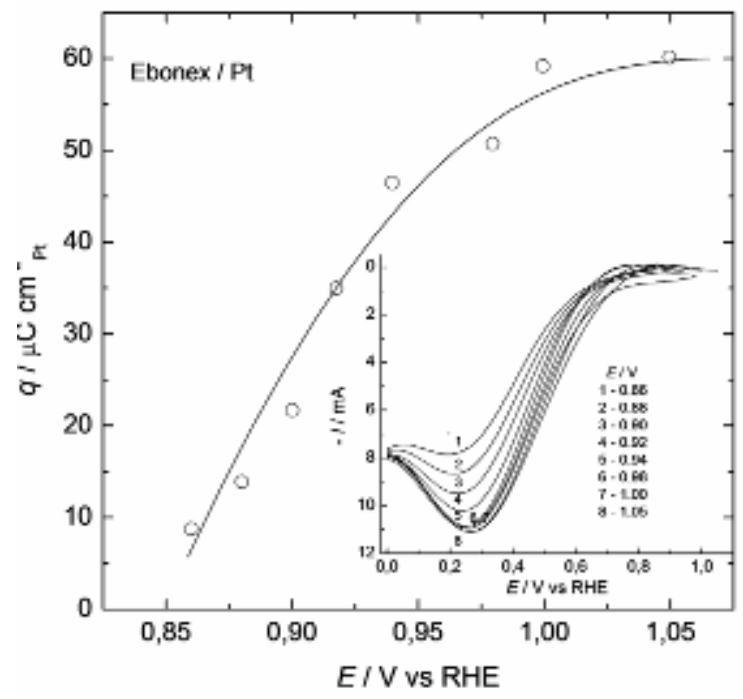

a)

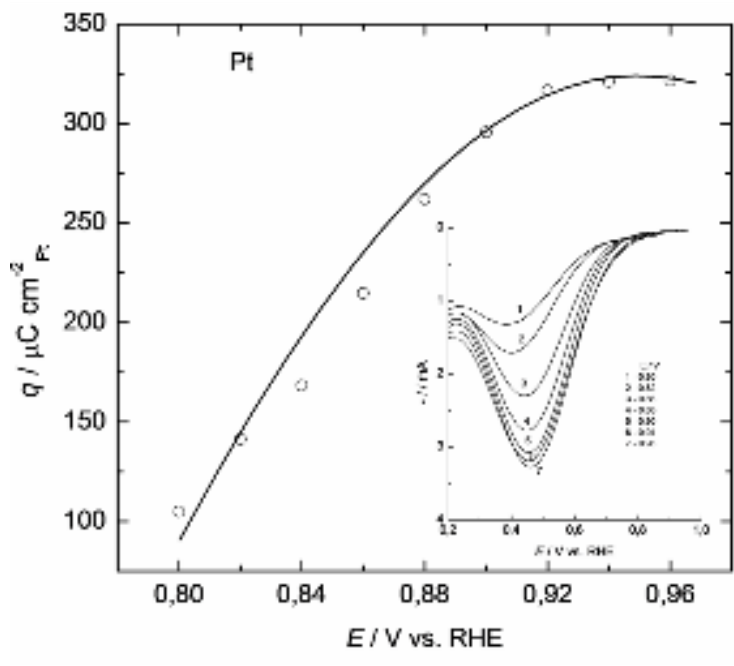

b)

Figura 6 - (a) Charge density (q) that required adsorbed oxygen species (Pt-OH/Pt=O) for their reduction, presented as a function of potential for $\mathrm{Pt} /($ Magneli phases) $(5 \mathrm{mg}$ ) electrode, same as in Fig. 5. The inset shows potentiodynamic I vs. E relations scanned from indicated different initial potentials (hold) with sweep rate of 5 V.s. scans and consideration by N. V. Krstajic). (b) The same as in (a), but for polycrystalline Pt metal

In such a respect, the guiding concept implies homogeneous nanostructured distribution and selective grafting while interactive hypo-hyper-d-dinterelectronic bonding of $\mathrm{Pt}(\mathrm{Au})$ nano-clusters upon various individual and preferably mixed valence hypo-d-oxide supports, taken for the reversible external interconnected latent storage and spillover $\mathrm{Pt}-\mathrm{OH}$ (Au-OH) sources, primarily $\mathrm{Nb}_{2} \mathrm{O}_{5}, \mathrm{TiO}_{2}$ (or $\mathrm{Ta}_{2} \mathrm{O}_{5}, \mathrm{TiO}_{2}$ ), because of their much 
advanced both stability and electronic conductivity. In such a constellation, nano-particles of solid oxides and $\mathrm{Pt}$ establish the SMSIs, the ones of strongest in the whole chemistry (Scheme 1, [4]), together with the electron conductive transfer, while external surface of hypo-d-oxide deposit undergoes spontaneous dissociative adsorption of water molecules and thereby becomes, along with continuous further water vapor supply (Scheme), the renewable and dynamically almost unlimited latent storage and spillover source of the Pt-OH.

\section{SPILLOVER PHENOMENA IN \\ ELECTROCATALYSIS OF THE ORR}

Spillover phenomena in general impose strong repulsion forces, when $\mathrm{RDS}$ intermediates $(\mathrm{Pt}-\mathrm{OH}$, $\mathrm{Pt}-\mathrm{H})$ partially transfer their charge to the metallic catalyst surface and become dipoles [15]. The driving force for such effusion effects imposes the gradient of electrochemical potential, which implies chemical potential for heterogeneous catalytic processes. Namely, the fundamental GuldbergWaage law of mass action predicts that the faster the spillover effect of the reacting intermediate species in the RDS, the faster the corresponding electrode reaction becomes.

\section{ADSORPTIVE DISSOCIATION OF WATER MOLECULES AND MEMBRANE TYPE SURFACE MIGRATION}

The first decisive step towards rather fast spillover widespreading phenomena of the $\mathrm{Pt}-\mathrm{OH}$ is the consequence of a strong first principle thermodynamic confirmed evidence (Density Functional Calculations, DFC) by Vittadini et al. [12], that water molecules undergo prevailing spontaneous dissociative adsorption on anatase and even rutile titania, and more so on the higher altervalent oxides [13] of tungsten, molybdenum, tantalum, niobium and/or cerium, etc., (Fig. 7), as the general oxophilicity properties of hypo-d-metals.

In addition, the first-principles moleculardynamic simulations showed the existence of a mechanism for thermodynamically favored spontaneous dissociation of water molecules even at low coverage of oxygen vacancies of the anatase (101) surface [13], and consequently at the Magneli phases, as substantially suboxide structure significant both as highly bulk electronic conductive, membrane type surface transferring hydroxide species and interactive catalyst support $[5,6]$. In fact, this is the status of reversible open circuit dissociative adsorption of water molecules at the equilibrium state, something like capillary phenomena in adsorption after some critical coverage extents. Meanwhile, in the presence of the nano-sized metallic part of the catalyst, and continuous enough moisture supply, directional electric field (or, electrode polarization), further disturbs such an established equilibrium and dynamically imposes further continuous forced dissociation of water molecules, and as the consequence, their membrane transport properties[14], (Eqs. (1-a), (1-b), (1-c)) summation $(\Sigma)$ yields Eq. (1), see the main part of this paper), definitely resulting with spillover features.
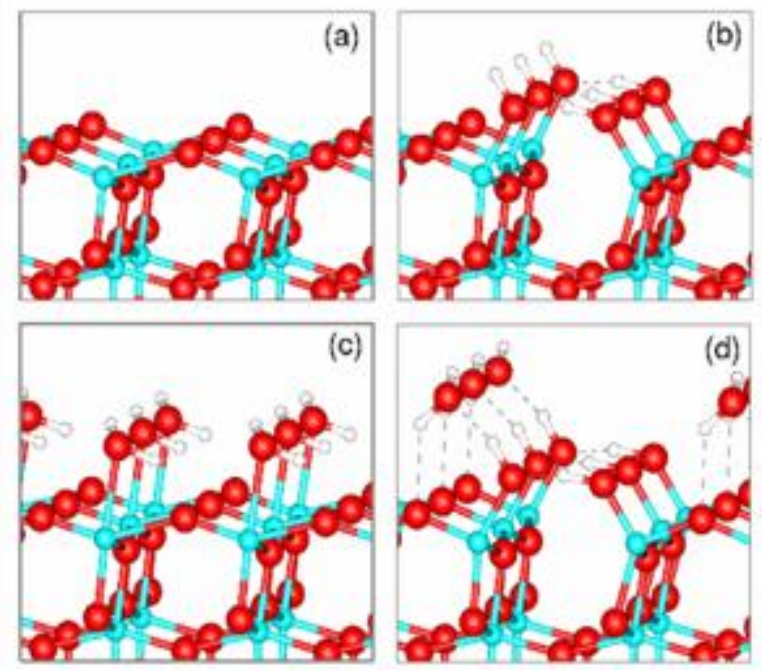

Figure 7 - The perspective views of DFT-optimized atomic structures for: (a) the clean anatase (ADM) ad-molecule model of unreconstructed (001) surface; (b) the dissociated state of water $(0.5$ monolayer) on (001); (c) the relaxed geometries of molecular state of adsorbed water (1.0 monolayer of hydroxylated anatase) on (001); and (d) the mixed state of water on (001) with a halfdissociated coverage of adsorbed monolayer water molecules (courtesy by A. Vittadini, cf. 12).

Such an oxide network, in particular of polyvalent (high altervalent numbers) hypo-delements, when in hydrous state, distinctly behaves as an ion exchange membrane even for the surface hydroxide migration. In fact, gels (aero and xerogels) are biphasic systems in which solvent molecules are trapped inside an oxide network, and such a material can be considered as a wateroxide membrane composite [14]. At the same time, the highly pronounced reversible potentiodynamic peaks testify for the extremely fast and independent overall spillover reaction (Eq. 1), in both directions [2,3], primarily used for DL charging and discharging pseudo-capacitance [4-6] and being always available for heterogeneous electrode reactions (see further downwards). 


\section{ELECTROCATALYTIC SPILLOVER PHENOMENA}

The first spillover phenomenon in heterogeneous catalysis was observed and defined by Boudart $[20,21]$ for the interactive supported bronze type $\left(\mathrm{Pt} / \mathrm{WO}_{3}\right)$ catalyst, initially at high temperature (above $400{ }^{\circ} \mathrm{C}$ ) for pure solid oxide system. Meanwhile, after the dissociative adsorption of water molecules on hypo-d-oxide supports of $\mathrm{Pt}$, the fast interactive effusion of $\mathrm{H}$ adatoms over its hydrated $\left(\mathrm{W}(\mathrm{OH})_{6}\right)$ surface becomes dramatically sped up even at ambient conditions in the ultimate presence of condensed at least monolayer aqueous precipitate, and vice versa, establishing capillary phenomena of speeding up effusion of the main catalytic reaction intermediates $(\mathrm{Pt}-\mathrm{OH})$. Such a striking sharp wetness impact upon the overall spillover phenomena associated with hydrated hypo-doxides in aqueous media, implies Ertel [18] autocatalytic molecular water effect, too, which states that the catalytic reaction of hydrogen oxidation upon $\mathrm{Pt}$ surface, even at deep low temperatures $\left(140{ }^{\circ} \mathrm{K}\right)$, proceeds with remarkable amounts of the $\mathrm{Pt}-\mathrm{OH}$, as the decisive and accumulated intermediate, including the self-catalytic step with adsorbed water molecules,

$$
2 \mathrm{Pt}+\mathrm{O}_{\mathrm{ads}}+\mathrm{H}_{2} \mathrm{O}_{\mathrm{ads}} \rightarrow 2 \mathrm{Pt}-\mathrm{OH}
$$

In fact, Ertel has pointed out the substantial overall significance of water molecules in heterogeneous catalysis for oxidation processes that in general proceed over the $\mathrm{Pt}-\mathrm{OH}$ generation and spillover.

This is significant both for the evidence of the extremely fast spillover widespreading and thereby resulting with imposed the reversible hydrated substrate reduction. The latter finally leads to the corresponding form of electrocatalytically active bronze $\left(\mathrm{Pt} / \mathrm{H}_{0.35} \mathrm{WO}_{3}\right)$ for cathodic processes, in which non-stoichiometric incorporated hydrogen obeys the same free reactive properties like adsorptive $(\mathrm{Pt}-\mathrm{H})$, and is the main source for the electrode or heterogeneous catalytic reactions. In other words, the point is that spontaneous dissociative adsorption of water molecules $[4,5,12,13]$ imposes much smaller activation energy for transformation of the resulting hydrated $\mathrm{W}(\mathrm{OH})_{6}$, into corresponding bronze state, and occurs even at ambient temperature, then behaving remarkably different than the initial solid oxide $\mathrm{WO}_{3}$, and thereby, dramatically facilitates the overall spillover effect under pronounced wet status (the activation energies thence being in the ratio of 2.2 , one with another). The alterpolar interchanges between the bronze type electrocatalyst and its hydrated state are correspondingly approved occurring instantaneously and reversibly fast, exactly because of the substantially facilitated Boudart [20,21] spillover effect and behave as a thermodynamic equilibrium $\left(\mathrm{Pt} / \mathrm{H}_{0.35} \mathrm{WO}_{3} \leftrightarrow\right.$ $\mathrm{Pt} / \mathrm{W}(\mathrm{OH})_{6}$ or, $\left.\mathrm{Pt} / \mathrm{H}_{\mathrm{x}} \mathrm{NbO}_{5} \leftrightarrow \mathrm{Pt} / \mathrm{Nb}(\mathrm{OH})_{5}\right)$.

Hypo-d-electronic transition metal oxides usually feature several altervalent states giving rise even to interactive mixed valence compounds, such as, for example, $\mathrm{TiO}_{2} / \mathrm{WO}_{3}, \mathrm{TiO}_{2} / \mathrm{Nb}_{2} \mathrm{O}_{5}$, $\mathrm{TiO}_{2} / \mathrm{Ta}_{2} \mathrm{O}_{5}$, or $\mathrm{TiO}_{2} / \mathrm{Nb}_{2} \mathrm{O}_{5} / \mathrm{CeO}_{2}$, and then correspondingly increase the overall latent storage and spillover effect of both $\mathrm{H}$-adatoms and primary oxides $(\mathrm{M}-\mathrm{OH})$. The whole spillover and SMSI effect behave typical synergistic electrocatalytic properties and never any individual hypo-d-oxide enables that much as mixed altervalent composites.

The problem so far was in unattainable nanostructured Pt-bronze, the catalytic activity of which exponentially increases with decreased $\mathrm{Pt}$ nano-size approaching maximum at monoatomic dispersion $[22,23]$. This requirement has now been fulfilled by the grafting implementation of $\mathrm{Pt}$ acetylacetonate within colloidal particles of peroxopolytungstic acid, niobia $\left(\mathrm{Nb}_{2} \mathrm{O}_{5}\right)$, tantalia $\left(\mathrm{Ta}_{2} \mathrm{O}_{5}\right)$ and ceria $\left(\mathrm{CeO}_{2}\right)$.

\section{ANODIC HCHO OXIDATION AND PRIMARY OXIDE SPILLOVER}

Since the heterogeneous reaction of formaldehyde oxidation with $\mathrm{Pt}-\mathrm{OH}$, and in particular $\mathrm{Au}-\mathrm{OH}$, proceeds as a fast reversible anodic process mass transfer limited, and since $\mathrm{HCHO}$ is soluble in all ratios in aqueous media, the primary oxide generation rate and its yielding spillover, have primarily been investigated by potentiodynamic spectra within the broader concentration range and between hydrogen and oxygen potential evolving limits (Fig. 8 a\&b). Such for an order faster anodic reaction is able to postpone within unusually long potential range the recombination of the primary $(\mathrm{Pt}-\mathrm{OH})$, into the more polarizable, more adsorptive and more stable surface oxide ( $\mathrm{Pt}=\mathrm{O})$, (Eq. 2).

Formaldehyde oxidation starts at its reversible potential $(0.32 \mathrm{~V} v s$. RHE), merges with the second UPD desorption peak of $\mathrm{H}$-adatoms, and extends as an exaggerated broad twins peak all along the anodic scan, nearly until the beginning of OER (Fig. 8a). In the same sense anodic $\mathrm{Pt}-\mathrm{OH}$ striping CO oxidation on composite hypo-d-oxides supported $\mathrm{Pt}$ or $\mathrm{Pt}, \mathrm{Ru}$ catalysts takes place even within the usual interval of UPD $\mathrm{H}$-adatoms desorption (Fig. 7, [22]). In other words, Pt-OH arises available for reaction not only within its nominal reversible adsorption/desorption peak limits in regular mineral acid or alkaline aqueous 
solutions, but depending on the reactant $(\mathrm{HCHO}$, $\mathrm{HCOOH}, \mathrm{CO}$, etc.) concentration, affinity and its actual reaction rate, along a broad and extendable potential range. Meanwhile, as the link of $D L$ charging/discharging, it actually extends and appears available all along the whole potential axis of cyclic voltammograms. Such an unusually broader charge capacity area (Fig. 8, a\&b), usually features all the properties of typical under- and over-potential oxidation (UPO,OPO) peaks, in particular when compared with cathodic UPD properties of $\mathrm{H}$-adatoms on various metals.
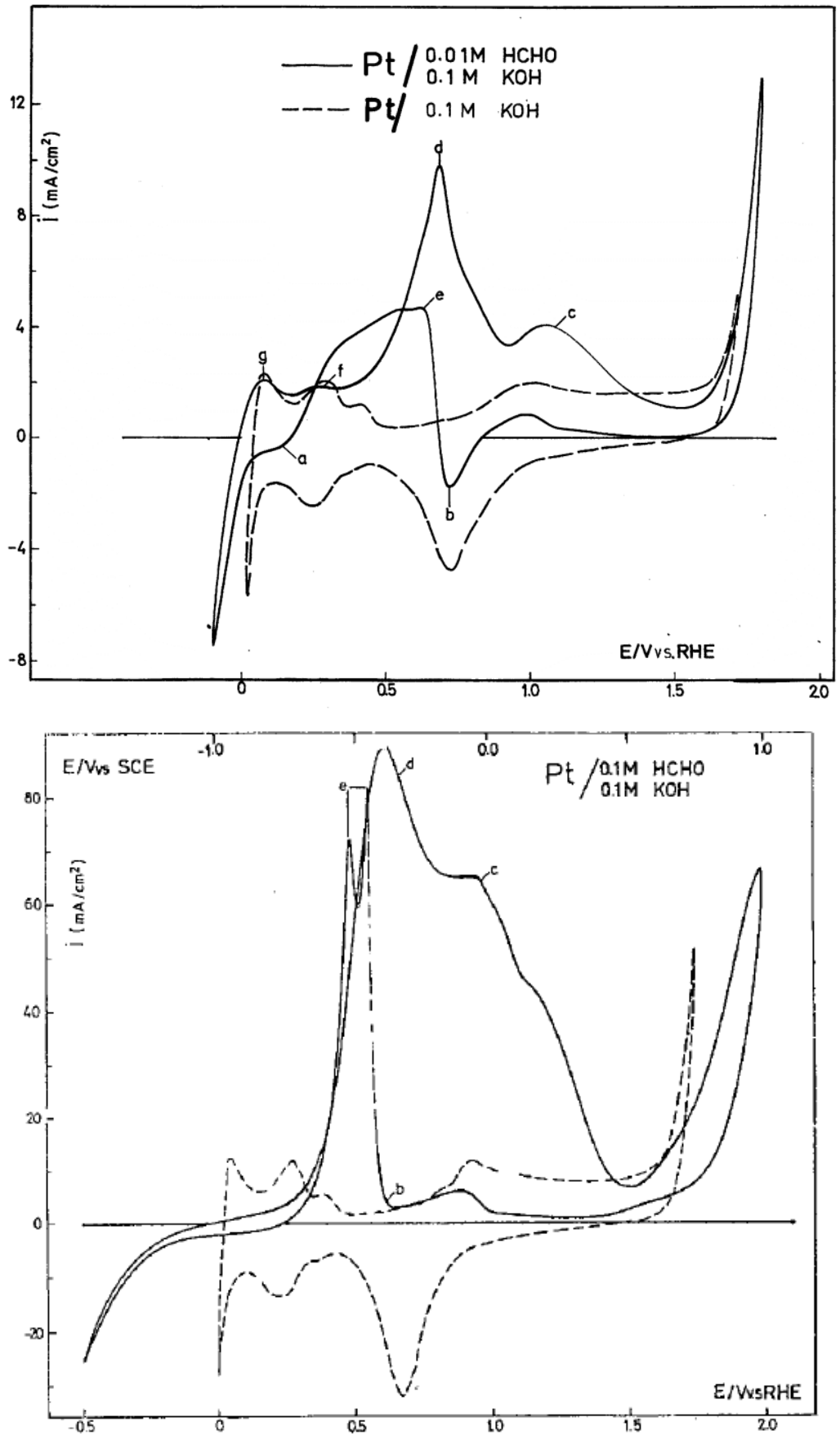

b)

Figure 8 - Cyclic voltammograms scanned on a polycrystalline Pt wire electrode in alkaline $(0.1 \mathrm{M} \mathrm{KOH}$, dashed lines) solution and in admixture of formaldehyde (0.01 M (Fig. 8a) and $0.1 \mathrm{M} \mathrm{HCHO}$ (Fig. 8b), full lines) at $200 \mathrm{mV} \mathrm{s}^{-1}$ sweep rate between hydrogen and oxygen potential evolving limits. Labels: (a) reversible hydrogen adsorption peak; (b) irreversible Pt surface oxide (Pt=O) desorption peak; (c and d) successive peaks of anodic aldehyde oxidation; (e) sudden sharp current jump and reverse peak of repeated $\mathrm{HCHO}$ oxidation in the course of successive cathodic scan; ( $g$ and f) reversible $\mathrm{H}$-adatoms oxidation and desorption peaks, respectively. (scans and discussion by C.M.Lacnjevac). 
Stepwise potential extension of positive potential limits toward the oxygen evolution reaction (OER), clearly shows (Fig. 8, a\&b) the absence of $\mathrm{Pt}=\mathrm{O}$ growth almost until oxygen starts evolving. Then, since during the reverse potential scan toward the HER, as the result of the former, there arises the $\mathrm{Pt}=\mathrm{O}$ desorption much earlier and of dramatically reduced charge capacity than in the simple acidic or alkaline solutions, the appearance of a characteristic sharp anodic current jump testifies for the hysteretic (cathodic sweep, anodic peak) aldehyde oxidation within the former $\mathrm{DL}$ charging/discharging range, and this way reflects the specific and highly reactive properties of the Pt$\mathrm{OH}$. In other words, as a corollary, there is no anodic aldehyde, alcohol, their simple acids, and even $\mathrm{CO}$ oxidation, nor the ORR, upon any $\mathrm{M}=\mathrm{O}$ $(\mathrm{Pt}=\mathrm{O}, \mathrm{Au}=\mathrm{O})$ covered metal surface prior to the potential of molecular oxygen evolution, when the latter becomes broken, but only upon prevailing Pt$\mathrm{OH}$ spillover deposits.

Namely, since aldehydes are often soluble in aqueous media almost in all ratios, their voltammograms at high contents feature imprinted extremely high both charge capacities and limiting currents at their peaks (Fig. 8b), and thereby testify for almost unlimited reversible reaction rates (Eq. 1), as long as diffusional mass-transfer supply provides enough reacting species. Even more so, for interactive supported $\mathrm{Pt}$ and $\mathrm{Au}$ upon higher altervalent hypo-d-oxides and their mixed valence compounds, since these behave as highly enriched latent storage capacities of primary oxide spillover sources $[16,17,28,29]$.

This is the cause and reason why within the reversible part of Tafel plots electrocatalytic metal $(\mathrm{Pt}, \mathrm{Au})$ surface is always covered by the interacting $\mathrm{Pt}-\mathrm{OH} / \mathrm{Pt}=\mathrm{O}$ species, and naturally tends to impose the reversible oxygen electrode properties, and these are experimental evidence that the optimal catalytic rate implies their optimal ratio.

Meanwhile, in such a context, one of the most outstanding observations has been that cyclic voltammograms of both formaldehyde (Fig. 4,[28]) and formic (muriatic) acid (Fig. 4, [29]) anodic oxidation distinctly differ upon plain (Pt/C) and the same, but more or less enriched supports in specific amounts of interactive hypo-d-oxide $\left(\mathrm{Pt} / \mathrm{Ta}_{2} \mathrm{O}_{5} / \mathrm{C}\right)$. In other words, the all parameters and conditions being the same, the reaction rate becomes dramatically different upon various supported electrocatalysts in their hypo-d-oxide amounts, as the result of distinctly different the additional Pt-OH spillover feeding and spreading effects, and as the only distinctly imposed difference. Such a conclusive observation belongs to the main experimental arguments to prove the theory of the $\mathrm{M}-\mathrm{OH}$ interfering self-catalytic spillover contributions in electrocatalysis of aqueous media, (Eq.3), [4-7], finally providing the ROE behavior and properties, and traced the way and entire approach for its substantiation. In such a respect, cyclic voltammograms deeper enlightened and more revealed the spillover reaction impact properties of the $\mathrm{Pt}-\mathrm{OH}$.

\section{POTENTIODYNAMIC SCANS OF PRIMARY OXIDE LATENT STORAGE AND \\ ELECTROCATALYTIC SPILLOVER SPREADING}

Some intermolecular compatible hypo-d-oxide mixed valence architecture $\left(\mathrm{Pt} / \mathrm{WO}_{3}, \mathrm{TiO}_{2} / \mathrm{C}\right.$, $\mathrm{Pt} / \mathrm{Nb}_{2} \mathrm{O}_{5}, \mathrm{TiO}_{2} / \mathrm{C}$ ), as the interactive catalytic submonolayer supports of high altervalent number or capacity, have been investigated by potentiodynamic scans to reveal both the primary oxide latent storage and resulting spillover yielding properties, along with same for $\mathrm{H}$-adatoms. In this respect, cyclic voltammograms scanned at low moisture content of $\mathrm{He}$ stream (just enough to enable basic electrode processes to proceed), insufficient for $\mathrm{WO}_{3}$ (or $\mathrm{TiO}_{2}$ ) hydration, repeatedly reveal similar potentiodynamic spectra characteristic for indifferent carbon supported $(\mathrm{Pt} / \mathrm{C})$, or plain Pt itself (Fig. 3), but with high double layer charging capacity, because of the accompanying parallel charging of Vulcan carbon particles beside the metal (with correspondingly large charge value, $\mathrm{Q}_{\mathrm{DL}}=1.07 \mathrm{C}$ ).

In contrast to such fairly common occurrences, a continuous supply of saturated water vapor in the He stream at higher temperature $\left(80^{\circ} \mathrm{C}\right)$, imposing condensation (Boudart spillover precondition [20, 21]), and leading to the appearance of wet titaniatungstenia mixed valence oxide composite, along with spontaneous dissociative adsorption of water molecules all over its exposed surface, as the interactive catalytic support, has been accompanied by the unusual phenomenon of a dramatic expansion of two reversible pairs of peaks of both the primary oxide high striking reversible values $\left(\mathrm{Q}_{\mathrm{Pt}-\mathrm{OH}(\mathrm{a})}=\mathrm{Q}_{\mathrm{Pt}-\mathrm{OH}(\mathrm{c})}=1.453 \mathrm{C}\right)$, and $\mathrm{H}$-adatoms (247 versus $47 \mathrm{mC} \mathrm{cm}^{-2}$, or in the ratio of about 5.3:1).) chemisorptive deposition and desorption (Fig. 3), like a DC capacitance of extremely developed electrode surface. Since these are highly reversible and evidently behave pronounced exaggerated high the latent $\mathrm{Pt}-\mathrm{OH}$ storage (cf. $[4,5,12])$, they keep the same their extents even after multiple and repeating number of cycles at any other time. The latter have both been of unusually high spillover charge and discharge capacity values and for Pt-OH (UPD and OPD) shifted towards both much more negative and far positive potential limits, in common with Fig. 6a\&b, and discussion thereon. In fact, two distinctly 
different cyclic voltammogram shapes and charge capacities (Fig. 3), appear only as the result of the difference in water vapor supply, all other parameters being unaltered the same, and as the effect of the equivalent dipole $(\mathrm{Pt}-\mathrm{OH})$ charging and discharging of the double layer, since nothing else takes place in between. Every cessation in the steam supply instantaneously imposes the sudden reversible shrinkage of both such rather exaggerated pairs of peaks down to the same initial potentiodynamic shape similar to the nanostructured $\mathrm{Pt} / \mathrm{C}$ voltammogram spectra themselves. Vice versa, the renewed saturate water vapor feeding immediately leads to their former Pt-OH peaks and the same former charge capacities; namely, the effect already noticed and scanned for formaldehyde [28] and formic acid [29] oxidation. Such an appearance without exception behaves as a typical reversible transient phenomenon by its endless altering repetition, and never appears upon the plain $\mathrm{Pt} / \mathrm{C}$ electrocatalyst, both wet and/or dry, nor with small and insufficient amounts of catalytic hypo-d-oxide supports.

The complementary interactive $\mathrm{Ta}_{2} \mathrm{O}_{5}$-based electrocatalytic support strongly reinforces just displayed potentiodynamic features of $\mathrm{Pt} / \mathrm{WO}_{3}, \mathrm{TiO}_{2} / \mathrm{C}$ by their coinciding and congenial spectral behavior: The distinct growth of $\mathrm{Pt}-\mathrm{OH}$ and $\mathrm{H}$-adatoms adsorption and desorption peaks, reflecting their different accumulated latent charge capacities, as a function of the amount (charge density) of interactive composite hypo-d-oxide deposits per unit electrode surface (Fig. 4) [16]. In fact, such Pt$\mathrm{OH}$ latent storage growth (including the corresponding spillover effect) does not extend endlessly and usually passes over remarkably pronounced maximum in the ORR catalytic rate and activity.

What is now the substantial difference between voltammograms in Fig. 3, wet state, and Fig. 8,a\&b (or Fig. 4)? Even when mostly suppressed in the surface oxide $(\mathrm{Pt}=\mathrm{O})$ adsorptive growth (Fig. $8, a \& b)$, the reversal backward cathodic scans on plain Pt proceed still highly polarized for about 600 $\mathrm{mV}$ with negligible or zero current, exactly corresponding to Fig. 1. In other words, there is still no stored $\mathrm{Pt}-\mathrm{OH}$ on plain $\mathrm{Pt}$ to start the selfcatalytic interfering reaction (Eq. 3 ) of the ORR, or $\mathrm{HCHO}$ oxidation. However, on the hypo-d-oxide interactive supported $\mathrm{Pt}$ catalyst, the a priori latently accumulated initial storage of the primary oxide from the beginning is ready and available, and thence, continuously provides and spillover enhances the latter to proceed as the uninterrupted and extra fast reversible electrode reaction, as long as there is continuous water vapor supply. However, for the plain $\mathrm{Pt}$ (or $\mathrm{Pt} / \mathrm{C}$ ), the sudden hysteretic sharp anodic current jump in the course of reversal cathodic sweep (Fig. 8, a\&b) rearises at and coincides with the classical position of the reversible peak for the $\mathrm{Pt}-\mathrm{OH}$ growth, reflects the local interfering self-catalytic effects at such potential range, provided by the repeated $\mathrm{Pt}-\mathrm{OH}$ spillover growth (Scheme). This is the striking point and the core substance of the present study, while Fig. 3, supported by Fig. 4, are the best illustrative issues of the substantiated reversible electrocatalyst for the oxygen electrode reactions (ORR, OER), (Eq. 3 and 4).

\section{CONCLUSION}

Classical potentiodynamic spectra in aqueous media, (Fig. 1), straight after adsorptive $\mathrm{Pt}-\mathrm{OH}$ peak, reveal unusual, anomalous, longer and stronger anodic polarization even within the thermodynamic equilibrium potential values $(\Delta \mathrm{E}=$ $\Delta \mathrm{E}_{0}+\eta_{\mathrm{r}}+\eta_{\mathrm{a}}$ ), and from the same cause and reasons, along the reverse cathodic sweep, too. Since the entire amount of reversibly adsorptive Pt$\mathrm{OH}$ sooner, out of the same reversible peak, undergoes complete disproportionation into highly polarizable and irreversibly deposited $\mathrm{Pt}=\mathrm{O}$ monolayer, (Eq. 2), and thereby becomes unavailable for further reaction within such a longer (about 600 $\mathrm{mVs}$ ) potential range, as the result, there imposes the typical pronounced reaction polarization, $\left(\eta_{\mathrm{r}}\right)$, which suppresses further proceeding of the interfering $\mathrm{Pt}-\mathrm{OH} / \mathrm{Pt}=\mathrm{O}$ reversible reaction (Eq. 3), within both scan directions. The latter extends further by the activation polarization $\left(\eta_{\mathrm{a}}\right)$, and all together they impose very strong and broad polarizable properties, Fig. 1). On the contrary, interactive (SMSI) supports of mixed valence hypo$\mathrm{d}$-(f)-oxides, a priori behave as continuously renewable and recoverable enormous (Pt-OH) latent storage capacities and spillover sources (Scheme) all along the potential range between oxygen and hydrogen evolving limits. Thus, there is now, under continuous $\mathrm{Pt}-\mathrm{OH}$ spillover supply, no reaction polarization, $\left(\eta_{r}=0\right)$, and since the OER occurs straight from the enormous broad Pt-OH peak, and thereby exactly at the thermodynamic ROE value, $\left(\Delta \mathrm{E}_{\mathrm{o}}=1.29 \mathrm{~V}, \eta_{\mathrm{r}}=\eta_{\mathrm{a}}=0\right)$, the reversible electrocatalysts of various interactive hypo-d-(f)oxide support compositions for oxygen electrode reactions (ORR, OER) have finally been substantiated and tested on Pt and $\mathrm{Au}$. The present conclusive discussion strongly asserts, implies and reveals why plain, non-modified Pt by no means can ever become reversible electrocatalyst for the oxygen electrode reactions, or at least not within the whole potential range between hydrogen and oxygen evolving limits (Fig. 1 and 2). 


\section{REFERENCES}

[1] W. R. Grove (1842) On a Gaseous Voltaic Battery. Philos. Mag. Series 3, 21 (140), 417-420. Reprinted: W. R. Grove (2012) On a Gaseous Voltaic Battery, Philos. Mag., 92 (31), 3753-3756.

[2] B. E. Conway (1995) Electrochemical Oxide Film Formation at Noble Metals as a Surface-Chemical Process, Prog. Surf. Sci., 49 (4), 331-452.

[3] H. Angerstein-Kozlowska, B. E. Conway, W. B. A. Sharp (1973) The Real Condition of Electrochemically Oxidized Platinum Surfaces: Part I. Resolution of Component Processes, J. Electroanal. Chem., 43 (1), 9-36.

[4] J. M. Jaksic, N. V. Krstajic, Lj. M. Vracar, S. G. Neophytides, D. Labou, P. Falaras, M. M. Jaksic (2007) Spillover of Primary Oxides as a Dynamic Catalytic Effect of Interactive Hypo-d-Oxide Supports, Electrochim. Acta, 53 (2), 349-361.

[5] M. M. Jaksic, G. A. Botton, G. D. Papakonstantinou, F. Nan, J. M. Jaksic (2014) Primary Oxide Latent Storage and Spillover Enabling Electrocatalysts with Reversible Oxygen Electrode Properties and the Alterpolar Revertible (PEMFC versus WE) Cell, J. Phys. Chem., C, 118 (17), 8723-8746.

[6] G. D. Papakonstantinou, J. M. Jaksic, D. Labou, A Siokou, M. M. Jaksic (2011) Spillover Phenomena and Their Striking Impacts in Electrocatalysis for Hydrogen and Oxygen Electrode Reactions, Adv. Phys. Chem., 201 (10), 1-22, Article ID 412165.

[7] J. M. Jaksic, G. D. Papakonstantinou, D. Labou, A. Siokou, M. M. Jaksic (2013) "Spillover Phenomena in Electrocatalysis for Oxygen and Hydrogen Electrode Reactions" in "New and Future Developments in Catalysis: Hybrid Materials, Composites, and Organocatalysts', S. L. Suib, Ed., Elsevier, Amsterdam, chapter 8, p. 175-212.

[8] Y. Ma, P. B. Balabuena (2007) Designing Oxygen Reduction Catalysts: Insights from Metalloenzymes, Chem. Phys. Lett., 440 (1-3), 130-133.

[9] L. Brewer (1968) Bonding and Structures of Transition Metals, Science, 161 (3837), 115-122.

[10] M. M. Jaksic (2000) Hypo-Hyper-d-Electronic Interactive Nature of Synergism in Catalysis and Electrocatalysis for Hydrogen Reactions, Electrochim. Acta, 45 (25-26), 4085-4099.

[11] S. J. Tauster, S. C, Fung, R. T. K. Baker, J. A, Horsley (1981) Strong Interactions in SupportedMetal Catalysts, Science, 211 (4487), 1121-1125.

[12] A. Vittadini, A. Selloni, F. P., Rotzinger, M. Gratzel (1998) Structure and Energetics of Water Adsorbed at $\mathrm{TiO}_{2}$ Anatase (101) and (001) Surfaces, Phys. Rev. Lett., 81 (14), 2954-2957.

[13] M. Lazzeri, A. Vittadini, A. Selloni (2001) Structure and Energetics of Stoichiometric $\mathrm{TiO}_{2}$ Anatase Surfaces, Phys. Rev. B, 63 (15), Article no.155409.

[14] J. Livage, M. Henry, C. Sanchez (1988) Sol-Gel Chemistry of Transition Metal Oxides, Prog. Solid State Chem., 18 (4), 259-341.
[15] M. T. M. Koper, R. A. Van Santen, Interaction of $H$, $\mathrm{O}$ and $\mathrm{OH}$ with Metal Surfaces, J. Electroanal. Chem., 472 (2) (1999) 126-136.

[16] Z. Awaludin, J. G. S. Moo, T. Okajima, T. Ohsaka (2013) $\mathrm{TaO}_{x}$ - Capped Pt Nanoparticles as Active and Durable Electrocatalysts for Oxygen Reduction, J. Mater. Chem. A, 1 (46), 14754-14765.

[17] K. Fugane, T. Mori, D. R. Ou, P. Yan, F. Ye, H. Yoshikawa, J. Drennan (2012) Improvement of Cathode Performance on $\mathrm{Pt}_{-} \mathrm{CeO}_{\mathrm{x}}$ by Optimization of Electrochemical Pretreatment Conditions for PEFC Application, Langmuir, 28 (48), 16692-16700.

[18] S. Volkening, K. Bedurftig, K. Jacobi, J. Wintterlin, G. Ertl (1999) Dual Path Mechanism for Catalytic Oxidation of Hydrogen on Platinum Surface, Phys. Rev. Lett., 83 (13), 2672-2675.

[19] M. Date, M. Haruta (2001) Moisture Effect on CO Oxidation over $\mathrm{Au} / \mathrm{TiO}_{2}$ Catalyst, J. Catal., 201 (2), 1221-1224.

[20] H. W. Kohn, M. Boudart (1964) Reaction of Hydrogen with Oxygen Adsorbed on a Platinum Catalyst, Science, 145 (3628), 149-150.

[21] J. E. Benson, H. W. Kohn, M. Boudart (1966) On the Reduction of Tungsten Trioxide Accelerated by Platinum and Water, J. Catal., 5 (2), 307-313.

[22] N. V. Krstajic, Lj. M. Vracar, V. R. Radmilovic, S. G. Neophytides, D. Labou, J. M. Jaksic, R. Tunold, P. Falaras, M. M. Jaksic (2007) Advances in Interactive Supported Electrocatalysts for Hydrogen and Oxygen, Surf. Sci., 601 (9), 1949-1966.

[23] M. Mavrikakis, P. Stoltze, J. K. Norskov (2000) Making Gold Less Noble, Catal. Lett., 64 (2), 101 106.

[24] B. Hammer, J. K, Norskov (1995) Why Gold is the Noblest of all the Metals, Nature, 376 (6537), 238240.

[25] P. Quaino, N. B. Luque, R. Nazmutdinov, E. Santos, W. Schmickler (2012) Why is Gold such a Good Catalyst for Oxygen Reduction in Alkaline Media? Angew. Chem. Int. Ed., 51 (52), 1-5.

[26] M. Haruta (2003) When Gold is not Noble: Catalysis by Nanoparticles, Chem. Rec., 3 (2), 75-87.

[27] C. Lina, Y. Song, L. Cao, S. Chen (2013) Oxygen Reduction Catalyzed by $\mathrm{Au}-\mathrm{TiO}_{2}$ Nanocomposites in Alkaline Media, ACS Appl. Mater. Interfaces, 5 (24), 13305-13311.

[28] J. Masud, M. T. Alam, T. Okajima, T. Ohsaka (2011) Catalytic Electrooxidation of Formaldehyde at $\mathrm{Ta}_{2} \mathrm{O}_{5}$-Modified Pt Electrodes, Chem. Lett. Japan, 40 (3), 252-254

[29] J. Masud, M. T. Alam, M. R. Miah, T. Okajima, T. Onsaka (2011) Enhanced Electrooxidation of Formic Acid at $\mathrm{Ta}_{2} \mathrm{O}_{5}$-Modified $\mathrm{Pt}$ Electrode, Electrochem. Commun., 13 (1), 86-89. 


\title{
IZVOD
}

\section{LATENTNO SKLADIŠTENJE PRIMARNOG OKSIDA (Pt-OH) KAO PODSTAKNUTOG IZVORA PRELIVANJA REVERZIBILNIH ELEKTROKATALIZATORA ZA ELEKTRODNO REAGOVANJE KISEONIKA}

\begin{abstract}
Latentno skladištenje primarnih oksida (Pt-OH, Au-OH) za podsticaj svojstava elektrokatalitičkog prelivanja $i$ sticanje osobina reverzibilne kiseonične elektrode (ROE), bilo je ustanovljeno $i$ ostvareno u oba smera duž čitave potencijalne ose između granica katodnog razvijanja vodonika $i$ anodnog izdvajanja kiseonika. Tako poboljšana elektrokatalitička svojstva podrazumevaju snažno interaktivno (SMSI - Snažna Interakcija Metal-Nosilac) usađujuće vezivanje nanostrukturisanih čestica (klastera) Pt (Au, RuPt) na kompozitnim altervalentnim hipo-d-(f)-oksidnim nosačima mešane strukture, koji ispoljavaju ekstra visoku stabilnost i naglašeno povećanu elektronsku provodljivost, naporedo sa disocijativnom adsorpcijom molekula vode, a samim tim rezultujuće obnovljivo latentno skladištenje primarnog oksida, neprekidnim napajanjem vodenom parom i membranskim tipom površinske migracije hidroksilnih jona. Ovi potonji, kao individualna vrsta, pod dejstvom polarizacije prenose pretežni deo elektrona na metalni deo elektrokatalizatora, odakle rezultuje Pt-OH (Au-OH) kao dipolna struktura i svojim površinskim odbijnim silama sledi reverzibilnu prelivajuću raspodelu i nameće elektrokatalitička $R O E$ svojstva preko čitave izložene katalitičke površine, odnosno dvojnoslojnog punjenja i pražnjenja pseudo-kondenzatora.
\end{abstract}

Ključne reči: Primarni oksid ( $P t-O H, A u-O H, M-O H)$; površinski oksid ( $P t=O, A u=O$ ); prelivanje; SMSI (Snazna Metal-Nosac Interakcija); d-(f)-metalna svojstva, UPD(OPD) (podpotencijalno i nadpotencijalno dvojnoslojno (DL) punjenje/pražnjenje pseudokapacitora; nanostrukturisan elektrokatalizator tipa bronze; reverziblna ćelija izmenjivog polariteta.

Naučni rad

Rad primljen: 14. 08. 2015.

Rad prihvaćen: 25. 09. 2015.

Rad je dostupan na sajtu: www.idk.org.rs/casopis 